\title{
Think global, act global
}

7 he interconnectedness of the 21 st century planet - with real-time telecommunications channels and the ability of everyday citizens to travel the globe-

necessitates that we think about the practice of neurology on an international scale. This issue of Neurology ${ }^{\circledR}$ Clinical Practice features a series of articles curated by David Clifford focusing on the importance of understanding the etiology, diagnosis, and management of neuroinfectious disease. In his series overview, Clifford observes: "The shrinking world we live in-where health problems anyplace in the world...can easily appear in our own communities- has given urgency to understanding and addressing global health problems." Featured articles discuss the intricacies of diagnosing and treating tuberculous meningitis (Chin) and acute encephalitis (Venkatesan et al.), and explore microbial DNA testing for inflammatory diseases of the brain (Takahashi et al.). Three case reports center on different manifestations of neuroinfectious disease.

In an article titled "Neurology goes global: Opportunities in international health," Fleisher and Mateen argue that there is a crucial need for neurologic expertise in resource-limited settings and offer practical advice about contributing in "ethical, informed, and sustainable ways in tandem with local health care providers when possible." This issue also features lively discussion among our authors and readers in our correspondence section, The Nerve! Shubhakaran and Khichar explain how osteoporosis is particularly vexing in the Indian population and offer advice for prevention and management.

Let this international focus embolden us to work together on small and large scales to improve the lives of our patients in meaningful ways.
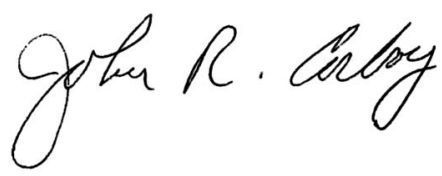

John R. Corboy, MD, FAAN

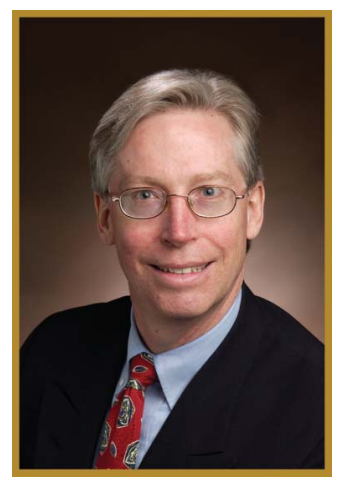

\footnotetext{
John R. Corboy, MD, FAAN
} 


\section{Neurology ${ }^{\circ}$ Clinical Practice}

Think global, act global

Neurol Clin Pract 2014;4;181

DOI 10.1212/CPJ.0000000000000038

This information is current as of June 9, 2014

Updated Information \& Services

Permissions \& Licensing

Reprints including high resolution figures, can be found at:

http://cp.neurology.org/content/4/3/181.full.html

Information about reproducing this article in parts (figures,tables) or in its entirety can be found online at:

http://cp.neurology.org/misc/about.xhtml\#permissions

Information about ordering reprints can be found online:

http://cp.neurology.org/misc/addir.xhtml\#reprintsus

Neurol Clin Pract is an official journal of the American Academy of Neurology. Published continuously since 2011, it is now a bimonthly with 6 issues per year. Copyright (C) 2014 American Academy of Neurology. All rights reserved. Print ISSN: 2163-0402. Online ISSN: 2163-0933.

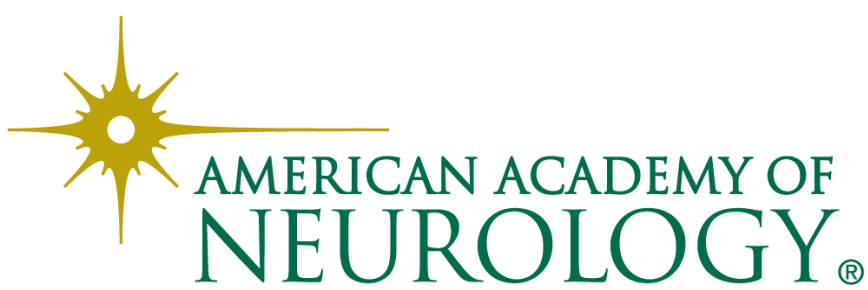

